\title{
Assessment as A Pedagogy and Measuring Tool in Promoting Deep Learning In Institutions of Higher Learning
}

\author{
Mfundo Mandla Masuku ${ }^{1}$, Nokukhanya Noqiniselo Jili² \& Primrose Thandekile Sabela ${ }^{3}$ \\ ${ }^{1}$ School of Development Studies, Faculty of Economics, Development and Business Sciences, University of \\ Mpumalanga, South Africa \\ 2 Department of Public Administration, Faculty of Commerce, Administration and Law, University of Zululand, South \\ Africa \\ ${ }^{3}$ School of Development Studies, Faculty of Economics, Development and Business Sciences, University of \\ Mpumalanga, South Africa \\ Correspondence: Mfundo Mandla Masuku, School of Development Studies, Faculty of Economics, Development and \\ Business Sciences, University of Mpumalanga, South Africa.
}

Received: October 7, 2020

doi:10.5430/ijhe.v10n2p274
Accepted: December 10, 2020

Online Published: December 11, 2020

\begin{abstract}
Traditionally, the key principle of assessment was based on the depth and intensity of the knowledge taught in class. In our modern state, the notion of assessment is more about learning and less about whether it is deep or surface learning. This could be attributed to challenges facing higher education, such as marketisation, massification, access and success. This article aims to demonstrate the significance of assessment as a pedagogical and measuring tool to promote deep learning in institutions of higher learning. It analyses how different types of assessment could contribute to deep learning while enhancing critical thinking and analytical skills. The article adopted the qualitative research approach to appraise critically and examine the literature on assessment in higher education. The sequence in which assessment tasks are presented, the pedagogical approaches adopted and measurement tools used should aim to present general non-threatening questions. The article recognises Bloom's taxonomy as it classifies educational learning objectives in the manner that accommodates deep learning. This article suggests that assessment should be made explicit, aligned with learning outcomes that consider deep learning in terms of acquisition of knowledge, comprehension, application, analysis, synthesis and understanding of basic concepts in what is learnt. It concludes that students need to be engaged in their assessment to enable them to develop skills and dispositions that prepare them for the future as socially responsible citizens. Research needs to be conducted on the higher education challenges that compromise the quality of assessment as this could have negative effects on the development of deep learning.
\end{abstract}

Keywords: assessment, deep learning, higher education, students, surface learning

\section{Introduction}

Multi-purpose higher education institutions are pluralistic in nature because of varied functions that need to be carried out. They are not expected to operate as silos because of a symbiotic relationship held with the work environment, public sector and society that shapes what is offered (Cleote \& Maasen, 2015; Murray, 2019). The institutions serve as producers of skilled workers and producers of scientific knowledge, including the function of being repositories and organisers of knowledge. They are regarded as intellectual centres in which analysts, critical thinkers, experts and policymakers are developed. The focus of higher education has, however, been challenged in that it has been given to both knowledge and learning to provide students with the opportunity to integrate knowledge into practice (Dall'Alba \& Barnacle, 2007). Hence, promoting students' learning and evaluating their knowledge, understanding, abilities and skills is crucial in higher education, and is ascertained primarily through assessment. An indispensable process in teaching and learning, the assessment helps students to extract the maximum benefit from their periods of formal learning, involving both structured and unstructured processes for gathering evidence and making judgements about students' competence and performance. In order to measure the quality of teaching and learning one needs to use appropriate strategies and tools to measure the performance of students, therefore, assessment is considered a crucial pedagogical instrument to enhance quality learning and to bring out qualities that are essential to preparing students for success and becoming socially responsible citizens. 
Boud (2007) and Medland (2016) indicate that assessment frames what students do and helps teachers to know whether students have mastered what they are supposed to learn based on the learning outcomes. Carless (2007) argues that assessment promotes learning and requires students to receive appropriate feedback which could be used to 'feedforward' into future work. It is designed to check whether the module outcomes relating to the unit standard have been met and whether the required level of competence has been achieved, both theoretically and practically. It determines students' learning, especially if the provision of sufficient feedback is made available to them, and it helps with further learning (Brunton et al., 2016). The formulation of tools has to be informed by the learning outcomes and assessment tasks, the principal consideration of which are whether they are appropriate to the module outcomes and level of study (NQF), as laid out in the various levels of Bloom's Taxonomy (Bloom et al., 1956). Students should have acquired the attributes aspired to, such as critical thinking, innovation, and problem-solving.

This article explores assessment in its various forms as pedagogy and as a measuring tool in promoting students' learning, abilities, skills and attributes that could enhance their character and lifelong learning. The qualitative approach was employed to appraise critically and evaluate the literature, specifically on assessment within the higher education environment. The approach involved exploring research findings and reports of various scholars considering assessment as the pedagogical and measuring tool to enhance deep learning. It follows a content analysis in identifying, classifying and interpreting dynamics of student assessment as a core pillar in effective teaching and learning strategy.

\section{Conceptualising Assessment in Higher Education}

According to Carless (2007), assessment is about grading and facilitating learning and measuring achievements. Sometimes it invokes comparison between students and can be used to support and enhance learning when it becomes a process of dialogue, comprehension and improvement rather than focusing on results (Shepard 2000; Santos Gururra 1993; Lopez-pastor \& Sicilia-Camacho, 2017). According to Camacho-Miñano et al. (2020), assessment is the process of providing evidence on the evaluation of students' learning progress and teaching lecturers' quality. It calls for aligning the learning demands of the lecturer and the understanding of students of such demands so that the focus is not on the outcome of learning but more on the process of learning.

Gibbs (1999) and Ghaicha (2016) wrote at length on assessment in higher education as the most powerful lever for deep learning which can either boost or undermine student learning The teachers have to influence the way students respond to a module and behave as learners. Yorke (2003); Gibbs \& Simpson (2004) and Gibbs (2006) emphasise that rather than learning being viewed solely as just a measurement tool it is also a process which supports the development of students. As assessment is based on the cognitive level of students, when setting assessment tasks the teacher has to look at Bloom's taxonomy with special focus on the categories that reflect knowledge, application, comprehension, synthesis and analysis. On the other hand, Bloxham et al. (2011) are of the view that assessment involves decentralised and subject-specific decision-making processes which are quality assured both within and outside the institution by different structures. Beck et al. (2013) express concern that higher education institutions lack assessment methods that adequately determine whether there are any gains in the intellectual development of students, gains described as longterm learning abilities and skills which enable students to learn on their own, approach problems from multiple perspectives and work with complex issues. Zlatkin-Troitschanskaia et al. (2016) have raised questions regarding the quality of assessment in higher education, particularly in developing countries where assessing large classes without technology assessment tools compromises its quality.

Surface and deep approaches to learning were firstly characterised in 1976 by Marton and Saljo, later reflected upon by Fernandes et al. (2012) as different learning styles influenced by the forms of assessment. The authors further acknowledge the extent of its contribution to lifelong learning and development of critical thinking and problemsolving abilities. Surface learning approaches imply passive engagement as students are motivated by a desire to complete a task without being motivated to learn in the process. The approach is characterised by a lack of reflection, memorisation, and reproduction of unrelated information and ideas for assessment purposes. Gibbs (2006) argues that surface learning could be encouraged by assessment systems which allow students 'to get away with not studying very much at all,' such as examinations (summative) which allow students to 'question spot' and avoid much of the curriculum. The concept of 'hidden curriculum' relates to surface learning in that it describes a situation in which students filter what to learn and pay attention to, not constructing their understanding of what is studied (Gibbs \& Simpson, 2004). Other concepts coined by Gibbs (2006) to describe the link between summative and surface learning behaviours are 'cue conscious, ' that is, awareness of what to study and what to leave out; 'cue seekers,' or trying by all means, to find out what questions would be in the examination, even asking for a scope; and 'cue deaf,' that is, disregarding information on the scope of work to prepare for the examination. 
Deep approaches to learning are related to high-quality learning outcomes, putting more effort into the active involvement of students in their learning and encouraging a deeper understanding of the work. Quesada et al. (2019) look at assessment as having social and pedagogical implications suggesting that active participation of students relates to achieving competencies for effective and professional performance. The latter refers to how students are assessed and the approach on which teaching and learning is based. The authors argue that students' participation in assessment is crucial and can take place during planning, development and final grading. It provides knowledge of the learning process and enhances deep learning as it furnishes students with increased possibilities to learn and self-regulate. Fernandes et al. (2012) argue that deep approaches to learning relate to learning that is motivated by a desire to understand and are characterised by an enquiring and critical stance. Students attempt to make sense of the materials and experiences, constructing their understanding in a type of learning that is closely linked to formative assessment and provision for feedback and feedforward functions. The assessment of student learning is a complicated process but is also the most important aspect of enhancing learning. The difficulty of validly measure the learning process using only one model is noted because of certain aspects that do not neatly fit the prescribed criteria. There are other tensions involved in determining assessment strategies that are reliable and could produce consistent and objective results. Some assessment tools are said to be so narrowly focused that they overlook certain technical competences, known as 'wicked competencies' (Winchester-Seeto et al., 2010).

\section{The Theory of Assessment in Higher Education}

The central goal of higher education centres on the growth and development of students more than the number who complete their degrees. The quality of education involves critical factors such as pedagogical instruction and the content of what is taught and learnt, with assessment playing a key role as a pillar to deep learning (Murray, 2019). The theoretical underpinnings of assessment in higher education focus attention on how to measure the quality of what is taught, what students learn and how to ascertain that learning has taken place. Ghaich (2016) alludes to the dichotomous concepts used in measuring and judging the extent to which learning has occurred, namely, examination, evaluation, tests and assessment. The author argues that the concepts are sometimes used interchangeably, which may suggest that they have a similar meaning. The definition of each concept is dependent on the context and learning theory adopted to facilitate learning. The assessment theory informing this article is derived from constructivism and social constructivism, based on a belief that these learning theories promote deep learning and assessment for learning rather than an assessment of learning.

The social constructionist perspective views learning as an active process of knowledge construction based on existing conceptions, and social interaction with others and with the environment (Kay \& Kibble, 2016). It proposes that knowledge is generated by a complex interaction between learners and the environment, helping them learn from each other by sharing knowledge and constructing knowledge through ongoing dialogue (Brenner, 2013; Jawitz, 2013). Learning takes place as a result of social interaction between students and society in which they function, and giving each other feedback on individual activities, sharing information and experiences. The lecturer facilitates the learning process and allows "students time to reflect on and evaluate what they have learnt and put new knowledge into context with respect to how it relates to what they already know" (Brenner 2013, p.46).

The constructionists and social constructionists believe that learning and assessment for learning is a collaborative process that involves sharing among students, with the lecturer providing guidance, facilitating the learning process and providing knowledge and support (Ghaicha, 2016). Assessment for learning leans more towards constructivism and social constructivism, in which formative assessments are regarded as of great worth (Ghaicha, 2016). The authors maintain that formative assessment is preferred within social constructivism, used as a means to gain essential feedback which enables the lecturer to trace the at-risk students, keep track of progress and plan for further development. Students engage with materials collaboratively and learn from each other, which encourages a deeper understanding and reinforcement of learning compounded by their becoming active and independent contributors to the development and evaluation of understanding. This suggests that assessment is an interactive process that enables engagement of all (students and lecturers) in a discussion of how to improve teaching and learning, performance and accomplishment of success (Ghaicha, 2016). The constructionists and social constructionists believe that students play a significant role in planning and monitoring their progress, thus enabling them to develop critical thinking and analytical skills while internalising knowledge and identifying individual strengths, weaknesses and opportunities.

The strength of the social constructionist theory rests on the presence of heterogeneous student groups that ensures a diversity of thought, experience and prior knowledge, which in turn provide them with an opportunity to share their expertise in areas reflecting their strengths. In the same understanding, assessment within constructivism and social constructivism encourages collaborative work and participation of students in the assessment process, enabling them 
to contribute to the construction of knowledge and achievement of their learning goals. Jimaa (2011) notes that the methods used to assess students are critical because of their influence on the learning process, having a deep impact on what and how the students study and the effectiveness of the whole learning process. Inappropriate methods of assessment could impose overwhelming pressure on students, culminating in wrong approaches to learning which may defeat the purpose of achieving lifelong learning. Despite the use of assessment as a tool to determine where students are in the learning continuum, reflecting on their learning contributes to the deepening of knowledge and prepares them for future engagements as responsible citizens.

This article proposes the adoption of assessment accountability as a model in assessing mastery of deep learning skills in the construction of knowledge and acquisition of academic content knowledge. The model takes note of assessment for learning whereby both the lecturer and students are acknowledged as active contributors to knowledge production and assessment for learning. The lecturer becomes accountable for the teaching and learning process and monitoring and assessment, including the feedout and feed-forward process. On the other hand, the students become engaged in the learning and assessment process, positioning themselves as active contributors to their development, assessment of understanding and performance.

\section{Challenges Inhibiting Deep Learning and Influencing Assessment Quality}

Higher education is expected to transform, liberate or free the individual, giving them a chance to reason and develop reasoning skills and critical thinking skills. Transformation of students is informed by what is taught, how it is taught, how the work is assessed and how students process the information. However, there are external and internal challenges that have a direct bearing on the performance of functions, roles and responsibilities of higher learning institutions, and that has an impact on the quality of assessments and how students learn. Some of these challenges are Marketisation and massification or class size. Commitment to the education for enlightenment, production of informed and critical citizens is influenced by these challenges to higher education, and the type of education fails to develop questioning, critical and a democratic attitude towards learning (Waghid, 2011).

Higher education is expected simultaneously to produce informed citizens, enhance scientific expertise and respond to market pressures and consumer demands. According to Ek et al. (2013), the focus tends to be on the employability of graduates and making education scientific through linking instruction to research. The Bologna process has also increased the focus on employability rather than knowledge production and acquisition. Marketisation relates to allocation of resources, determined by the number of students enrolled and their performance or through-put. Since universities receive funding from the state calculated by the number of graduates, the pressure is on academics to encourage 'microwaved degrees.' Assessment is viewed as a tool for grading purposes rather than the development of deep learning, essential critical thinking skills and internalisation of knowledge.

Linked to Marketisation is the evaluation and ranking of universities based on research outputs using quantifiable measures, such as the number of articles that have been produced and published in accredited journals. This could compromise quality in the teaching and assessment of students. Ek et al. (2013, p.1306) claim that higher education is exposed to paradoxical tension, stating that "it is necessary to communicate and collaborate with society and the market, on the other hand, the organisation has been influenced by business ideals to a point where researchers are above all rewarded for publications addressing other researchers." Universities are also allocated more resources for research achievements and recognised for the number of SAPSE-recognised articles published. The issue of "publish or perish' (Waghid, 2011) has seen an increase in research outputs for personal gain, which when used as compliance for funding purposes and promotion could compromise pedagogical practices and assessment as a means towards deep learning. Maassen and Cloete (2006) and Ek et al. (2013) acknowledge that higher education institutions have adopted an industry-wide approach, and the scientific community believes that higher education is increasingly driven by economic demands, with less emphasis on knowledge production.

Pressure on higher education institutions to change from being centres of learning to business organisations with productivity targets has failed to recognise that these institutions are supposed to promote knowledge production, critical thinking and meeting of social and economic development needs of society. However, the academic system itself encourages profit-driven operations and self-interest among academics. Who can have the desire to teach, assess and develop essential skills if climbing the ladder is dependent on publications and if more incentives or rewards are given to those who publish in accredited journals? Lynch (2006) notes that the universities aspire to climb and be high on the global league table, which symbolically is the most powerful indicator of incorporation of market values into the university.

Positive political-economic implications of massification are noted by Tlali et al. (2019), arguing that an increase in enrolment signifies a positive sign of democratisation of access to higher education. However, the wild penning of 
academic gates in higher education has implications for the quality of teaching and learning. This article contends that massification compromises the promotion of deep learning in that it hinders the production of adequately qualified and trained students with the requisite knowledge, competences and skills to effectively contribute to the social and economic advancement of the country. Hornsby \& Osman (2014) argue that a correlation exists between class size and student performance. The widening of access and increase in class size, for example, has been viewed by lecturers as a challenge, hence massification is described as an unfortunate trend in the academic discourse (Lynch \& Pappas, 2017). Lecturers become overwhelmed with materials to be assessed, such as individual assignments, and they find it challenging to have consultations with students. This compromises quality of teaching and learning (Tlali et al., 2019).

Hornsby et al. (2013) claim that class size matters in relation to educational goals and the quality of experience in that they not only include knowledge acquisition (surface learning) but also promote student engagement and higher order cognitive functions (deep learning). Smaller classes are associated with attempts to individualise instructions and a better classroom climate. The current work environment requires students who can think holistically, who can come up with innovative solutions, critically reflect and think differently, with good interpersonal skills for teamwork. It should also be acknowledged that students have unique differences and thinking preferences which characterise the approaches adopted to problem-solving.

It is believed that students learn much better if teaching and learning is informed by the theories of learning which put emphasis on the aspect of diversity, social interaction, transformative and collaborative learning. Kay \& Kibble (2016) view learning and development as a social process whereby learners grow into the intellectual life of those around them. They are afforded an opportunity to participate in class, interact and become actively engaged in their learning process. It is proposed that 'good learning' occurs when there is actual development and when students work independently with adequate support from knowledgeable others who scaffold the knowledge or skills acquisition process. If class discussions do take place they tend to be superficial, without any lengthy discussions. Increased access to education translates into having large classes that are criticised for encouraging rote learning and surface learning rather than critical thinking and deep learning (Willems, 2013). Though it is claimed that students learn much better when active and when they have more opportunity for feedback, it becomes difficult for lecturers to provide timeous and appropriate feedback (Willems 2013; Lynch \& Pappas, 2017).

\section{Aligning Assessment with Teaching and Learning}

The concept of constructive alignment is based on a belief that diverse and larger classes create difficulty in maintaining academic standards, with an existing nexus between teaching and learning and assessment (Biggs, 1999; Murray, 2019). It is contended that when all components are aligned the students can achieve high order learning. Constructive alignment is often seen as the most powerful student learning tool available to higher education teachers (Orsmond \& Merry, 2017). Teachers are therefore expected to organise the teaching and learning context such that the outcomes indicate the kind of understanding required from students, and that the learning activities achieve those understandings. They should also ensure that the assessment tasks tell students what activities are required of them and how well the outcomes have been achieved. Constructive alignment is, therefore, a teaching system that aligns the intended learning outcomes, what should be learnt with the teaching methods, learning activities and the assessment strategies or the means of ascertaining the levels of understanding, knowledge and application. The focus of teaching and learning is not on what teachers teach but what they would like the students to learn and how students could be assisted to achieve deep learning.

Wilson \& Scalise (2006) maintain that constructive alignment suggests the desirability of achieving goodness of fit between learning outcomes, instructional approach and assessment. It is further noted that an effective educational system is one in which all aspects of teaching and assessment are integrated to support deep learning. Carless (2007) emphasises that all assessments have to lead to student learning but the fundamental challenge is to stimulate the right kind of learning. The author also proposes a concept similar to constructive alignment, termed 'learning-oriented assessment' (LOA), the conceptualisation of which holds that the assessment tasks have to embody the desired learning outcomes for students to achieve deep learning experiences whilst progressing to the outcomes. Carless (2007, p.59) further states that "the tasks should promote the kind of learning dispositions required of graduates and should mirror real-world applications of the subject matter." This could be achieved when lesson plans are designed in a way that the learning objectives, teaching and learning activities, and assessment strategies employed in evaluating students learning, are well aligned with one another. Carless (2007) believes that student involvement in assessment heightens understanding of learning and enables them to engage more with criteria and standards. Learning-oriented assessment is proposed on the basis that students develop a better and deeper understanding of learning goals and it allows students to be cognisant of the criteria of assessment and monitoring their progress towards the stated standards. 
Formative assessments are effective for improving student learning if followed by constructive feedback and effective instructional responses, such as reviewing and re-teaching. It is important that feedback is delivered as soon as possible and sufficiently detailed to be considered developmental. Assessments focusing on deep learning require oral, written and detailed feedback. Peer feedback is also desirable, although Gibbs (2006) raises concern about the variable quality and uncertain marking standards. It is assumed that feedback can assist in improving the manner in which students learn and their performance. Further, peer assessment provides them with an opportunity to internalise academic standards and encourages them to produce a better product through fear of having their work checked or marked by peers.

\section{Methods of Formative Assessment Used to Promote Deep Learning}

After discussing practical ways in which deep learning can be promoted, a discussion in this article also considers different types of formative assessments that could help both parties (teacher and the student) to have cooperation in the journey of teaching and learning. Teachers should understand different models of assessing students in the process of promoting deep learning. Naidoo \& Mthembu (2015) express concern that academics at higher learning institutions are increasingly challenged to facilitate the learning of both postgraduates and undergraduates from different backgrounds by innovative and progressive methods that foster deep learning and critical inquiry. To enhance the student learning process the following models can be used.

\subsection{Group-based Assessment}

Group-based assessment is mostly implemented in large classes and allows the teacher to assess the learning process as well as its products (Luckett \& Sutherland, 2000; Biggs, 2011; Khuzwayo, 2018). This assessment approach assists in the development of important competencies such as collaborative learning, teamwork skills and learning to work with diverse groups, interpersonal communication, feedback, and facilitation skills. The only envisaged problem is mark allocation because of the difficulty encountered in establishing the actual contribution made by individual group members to the group project. Khuzwayo (2018) expresses concern that marks shared by individuals from group assessment do not usually fairly reflect student performance. Khuzwayo (2018) shares the sentiments of Shay (2008) that marks scored by the group require rigorous moderation to address lack of fairness in the distribution of marks among individuals. Group conflicts might arise, aggravated by the cultural diversity of backgrounds, faculties and departments, in terms of discipline, culture and educational background (Seifert \& Feliks, 2019).

\subsection{Peer Assessment and Self-assessment}

It is crucial to ask for peer talk frequently in terms of pair work, especially in undergraduates' and honours classes. Peer assessment utilises cooperative learning exercises intending to develop students with lower competence through the assistance of more skilful peers within the zone of proximal development (ZPD) (Vygotsky 1978). This way of building knowledge is validated by Vygotsky's (1978) social constructivism and Thomas's (2009) "problem-posing" education, both of which emphasise thinking and searching for knowledge through dialogue and interaction, as well as teachers' and students' joint responsibility for the learning process. Self-assessment allows students to understand and judge their learning and identify their contribution to the given tasks. McMillan \& Hearn (2008) note that it occurs when students judge their work to improve performance as they identify differences between current and desired performance. The concept of self-assessment has three interrelated components, namely, self-monitoring, selfjudgement (which includes learning targets), and corrective measures. Self-monitoring is an essential skill which creates awareness in thinking and progress as it occurs. Students are expected to pay special attention to what they are doing in relation to external standards. The second component, self-judgement, involves identifying progress towards targeted performance. Based on established standards (benchmarks) and criteria (guidelines), students are expected to be able to express what they know and what they still need to learn. The last component in self-assessment focuses on the selection of learning goals and activities to improve on performance, taking corrective measures when necessary, and extending learning. However, Biggs (2011) has raised concern that peer and self-assessment can be nerve-racking for some students, particularly good ones, who normally under-assess themselves, while underperforming students over-assess themselves. However, Biggs (1999) does note that peer assessment is a useful strategy for reducing marking time for assessors who are dealing with large classes.

\subsection{Oral Presentation Assessment}

Across higher education, assessment of presentation skills is gradually being encouraged to enhance the communication skills of students (Pickford \& Brown 2006). The oral assessment is highly personalised and arguments cannot be presented without knowing the topic and planning it accurately, both of which encourage students to become more interested in their studies. The teacher not only listens to the arguments but must also observe the reaction of the 
students and draw conclusions about the commitment to their argument. Pearce \& Lee (2009) note that the skills that are usually evaluated in oral presentations are knowledge of the subject, confidence, concision of the response, quality of response, thinking on the spot, communication skills, application of theory to practice, ability to handle questions, body language, professional manner, and clarity of responses. This approach enables students to learn to organise an argument using evidence and to engage critically with the idea, thereby enhancing personal mastery of the course learning. In order to promote deep learning and to ensure a fair, authentic, reliable and valid grading it is important to look at the assessment criteria and grading descriptors.

\section{Assessment Criteria and Grading Descriptors}

Clear assessment criteria provide guidance, greater objectivity in marking, and more efficient communicating of feedback, contributing significantly to student learning. The grading rubric is to be explained to students so that they clearly understand how their performance is going to be measured as this will help them to prepare their work accordingly. The question arises as to how they should be designed and who should be involved. Bloxham et al. (2011) expressed a great concern that teachers sometimes ignore the use of criteria and choose not to use implicit standards in assessing students. It is acknowledged that the application of assessment criteria is a complex task which involves professional judgement rather than measurement. The central importance of validity and reliability in assessments cannot be ignored, as they are considered as the criteria for ensuring that assessment information means what it is supposed to mean. This means that the depth of knowledge and the cognitive level of the tasks should match and the scores obtained reflect the actual performance. Bloxham et al. (2011) further noted the disjunction between beliefs adopted by teachers and the actual grading practice. Transparency and judgement in assessment is essential, with Bloxham \& Boyd (2012) arguing that assessment practice is based on false assumptions about knowledge that it is monolithic, universal or static. Moreover, there is also a question about the approach to be adopted, whether normreferencing or criterion-referencing. Norm-referencing is comparative and not linked to the achievement of outcomes and is insensitive to changes in students' learning (Knight, 2002). It indicates a student's grade with reference to others in the cohort, whereas criterion-referencing identifies what counts as successful performance or good attainment. It involves the use of descriptors. The concern is raised about assessment tools and grading criteria which are commonly used because the scores given in percentages tend to be silent and not informative and fail to indicate what students have learnt (Knight, 2002). However, it is noted that more informative transcripts could sprawl into long lists of statements of achievements and therefore be ignored.

Knight (2002) \& Winchester-Seeto et al. (2010) emphasise that scores and grades are again silent about the learning process involved, arguing that to judge the robustness of an achievement one has to know something about its circumstances. This indicates that the quality of a learning process is evidence of the robustness of informal learning. Some grades or classifications are based on examinations only (summative assessment), which tends to promote the adoption of surface approaches to learning which have implications for the learning achieved and the process of learning. However, it should be noted that workload issues are regarded by many teachers as contributing to the design of tools that fail to adequately and accurately measure student learning. A rubric is an explicit set of criteria for assessing performance and it provides detailed information on how work is assessed (Andrade, 2000; Chan et al., 2019). The rubric for an assignment has the criteria and grading scores with a detailed explanation of how the scores are achieved. Grading a student's performance involves drawing an inference from what the student produces. The quality of the inference depends on several factors, including the quality of students' answers during the assessment process. Moreover, an ambiguous item is unlikely to give rise to good-quality data because different students will probably interpret the item differently. The teacher needs to set up a task that has one or more of the following components: problem to be solved, a question to be answered, an issue to be addressed, or a position to critiqued or defended with evidence (Sadler, 2016). The descriptors indicate how the scores are derived and what is expected of the students, including the level of performance that students are expected to demonstrate.

\section{Conclusion}

The article has addressed issues which need to be taken into consideration when designing and implementing good quality, valid and reliable assessment methods, tools or techniques. The effective assessment constitutes deep learning and the focus has to be on providing guidance and feedback towards the achievement of learning outcomes. The aim of assessment should be to assist students to develop critical thinking skills and enable them to construct knowledge and identify weaknesses in their learning process. It revealed that the assessment has to be structured in such a way that it is possible to observe the levels of cognitive demand placed on students. Assessment tasks have to encourage and reinforce a deeper approach to learning, increased objectivity in the grading of students, and the provision of timeous feedback. It is recommended that teachers develop and explain to students a grading tool to ensure the quality 
of the assessment process. Hence, it has emphasised that good assessment practise needs to be undertaken to encourage deep learning based on learning outcomes. The assessment tasks should always match the stated learning outcomes and the marking criteria should be known by the students before the actual assessment. Assessment should not only be about grading the performance of students but also should focus more on what students were asked to learn and reflect on the methods that can be used to improve their learning. This suggests that assessment has to be flexible, relevant and meaningful to ensure that it nurtures deep learning. To achieve deep learning through assessment, the focus should be on the process rather than the end-product (passing the module). Assessment as a pedagogical instrument for measuring and promoting deep learning requires an understanding of the assessment processes, criteria and standards, with the involvement of students in the construction of assessment tools.

\section{References}

Andrade, H. G. (2000). Using rubrics to promote thinking and learning. Educational leadership, 57(5), 13-19.

Beck, R. J., Skinner, W. F., \& Schwnbrow, L. A. (2013). A Study of Sustainable Assessment theory in Higher Education Tutorials. Assessment \& Evaluation in higher Education, Vol 38 (3), 326-348. https://doi.org/10.1080/02602938.2011.630978

Biggs, J. (1999). What the Student Does: teaching for enhanced learning. Higher Education Research \& Development, Vol 18 (1), 57-75. https://doi.org/10.1080/0729436990180105

Biggs, J. B. (2011). Teaching for quality learning at university: What the student does. McGraw-hill education (UK).

Bloom, B. S., Engelhart, M. D., Furst, E. J., Hill, W. H., \& Krathwohl, D. R. (1956). Taxonomy of educational objectives: Cognitive domain, 1, 20-24. Longman Group.

Bloxham, S., Boyd, P., \& Orr, S. (2011). Mark my Words: the role of assessment criteria in UK higher education grading practices. Studies in Higher Education, 36(6), 655-670. https://doi.org/10.1080/03075071003777716

Bloxham, S., \& Boyd, P. (2012). Accountability in grading student work: Securing academic standards in a twentyfirst century quality assurance context. British Educational Research Journal, 38(4), 615-634. https://doi.org/10.1080/01411926.2011.569007

Boud, D. (2007). Reframing assessment as if learning were important. In Rethinking assessment in higher education, (pp. 24-36). Routledge. https://doi.org/10.4324/9780203964309

Brenner, E. (2013). Giving Every Student a Voice: the use of an interactive classroom technology in large classes. In Hornsby, D. J.; Osman, R \& De Matos-Ala (Eds.). 2013. Large Class Pedagogy: Interdisciplinary Perspectives for Quality Tertiary Education. Johannesburg: Sun Media Metro.

Brunton, J., Brown, M., Costello, E., \& Walsh, E. (2016). Designing and Developing a Programme-Focused Assessment Strategy: a case study. Open Learning, 31(2), 176-187. https://doi.org/10.1080/02680513.2016.1187593

Camacho-Miñano, M. D. M., del Campo, C., Urquía-Grande, E., Pascual-Ezama, D., Akpinar, M., \& Rivero, C. (2020). Solving the mystery about the factors conditioning higher education students' assessment: Finland versus Spain. Education + Training, 62(6), 617-630. https://doi.org/10.1108/ET-08-2019-0168

Carless, D. (2007). Learning-oriented assessment: conceptual bases and practical implications. Innovations in Education and Teaching International, 44(1), 57-66. https://doi.org/10.1080/14703290601081332

Chan, K. K. H., Rollnick, M., \& Gess-Newsome, J. (2019). A Grand Rubric for Measuring Science Teachers' Pedagogical Content Knowledge. In Repositioning Pedagogical Content Knowledge in Teachers' Knowledge for Teaching Science, (pp. 251-269). Springer, Singapore. https://doi.org/10.1007/978-981-13-5898-2_11

Cloete, N., \& Maassen, P. (2015). Roles of Universities and the African Context. In Cloete, N.; Maassen, P. \& Bailey, T. 2015. Knowledge Production and Contradictory Function in African Higher Education. Cape Town: African Minds.

Dall'Alba, G., \& Barnacle, R. (2007). An Ontological Turn for Higher Education. Studies in Higher Education. Studies in higher education, 32(6), 679-691. https://doi.org/10.1080/03075070701685130

Ek, A., Ideland, M., Jonsson, S., \& Malmberg, C. (2013). The tension between Marketisation and Academisation in Higher Education. Studies in Higher Education, $1305-1318$. https://doi.org/10.1080/03075079.2011.619656 
Fernandes, S., Flores, M. A., \& Lima, R. M. (2012). Students' Views of Assessment in Project-led Engineering Education: findings from a case study in Portugal. Assessment \& Evaluation in Higher Education, 37(2), 163178. https://doi.org/10.1080/02602938.2010.515015

Ghaicha, A. (2016). Theoretical Framework for Educational Assessment: A Synoptic Review. Journal of Education and Practice, 7(24), 212-231.

Gibbs, G. (1999). Using assessment strategically to change the way students learn. In assessment matters in Higher Education, edited by S. Brown and A. Glasner, 41-54. Buckingham: Open University Press.

Gibbs, G. (2006). How assessment frames student learning. In Innovative assessment in higher education (pp. 43-56). Routledge.

Gibbs, G., \& Simpson, C. (2004). Does your assessment support your students' learning. Journal of Teaching and learning in Higher Education, 1(1), 1-30.

Hornsby, D. J., \& Osman, R. (2014). Massification in higher education: Large classes and student learning. Higher education, 67(6), 711-719. https://doi.org/10.1007/s10734-014-9733-1

Hornsby, D. J., Osman, R., \& De Matos-Ala. (2013). Teaching Large Classes: Quality Education Despite the Odds. In Hornsby, D. J.; Osman, R \& De Matos-Ala (Eds.). 2013. Large Class Pedagogy: Interdisciplinary Perspectives for Tertiary Quality Education. Johannesburg: Sun Media Metro. https://doi.org/10.18820/9780992180690

Jawitz, J. (2013). A Battle to be Waged outside the Classroom: the Challenge of Teaching Large Classes in Higher Education in South Africa. In Hornsby, D. J. https://doi.org/10.18820/9780992180690/09

Jimaa, S. (2011). The Impact of Assessment on Students Learning. Procedia - Social and Behavioral Sciences, 28, 718-721. https://doi.org/10.1016/j.sbspro.2011.11.133

Kay, D., \& Kibble, J. (2016). Learning Theories 101: Application to Everyday Teaching and Scholarship. Advances in Physiological Education, 40, 17-25. https://doi.org/10.1152/advan.00132.2015

Khuzwayo, M. E. (2018). Assessment of group work in initial teacher education and training. South African Journal of Education, 38(2), 1-11. https://doi.org/10.15700/saje.v38n2a1386

Knight, P. (2002). Summative Assessment in Higher Education: practices in disarray. Studies in Higher Education, 27(3), 275-286. https://doi.org/10.1080/03075070220000662

López-Pastor, V., \& Sicilia-Camacho, A. (2017). Formative and shared assessment in higher education. Lessons learned and challenges for the future. Assessment \& Evaluation in Higher Education, 42(1), 77-97. https://doi.org/10.1080/02602938.2015.1083535

Luckett, K., \& Sutherland, L. (2000). Assessment practices that improve teaching and learning. http://ahero.uwc.ac.za/index.php/?module=cshe\&action=viewtitle\&id=cshe_92. Accessed 20 March 2020.

Lynch, K. (2006). Neo-liberalism and marketisation: The implications for higher education. European educational research journal, 5(1), 1-17. https://doi.org/10.2304/eerj.2006.5.1.1

Lynch, R. S., \& Pappas, E. (2017). AModel for Teaching Large Classes: Facilitating a Small Class Feel. The International Journal of Higher Education, 6(2), 199-212. https://doi.org/10.5430/ijhe.v6n2p199

Marton, F., \& Säljö, R. (1976). On qualitative differences in learning: I-Outcome and process. British journal of educational psychology, 46(1), 4-11. https://doi.org/10.1111/j.2044-8279.1976.tb02980.x

Maassen, P., \& Cloete, N. (2006). Global reform trends in higher education. In Transformation in higher education, (pp. 7-33). Springer, Dordrecht. https://doi.org/10.1007/1-4020-4006-7_2

McMillan, J. H., \& Hearn, J. H. (2008). Student Self-Assessment: the key to stronger student motivation and higher achievement. Journal of Education Horizons, 87(1), 40-49.

Medland, E. (2016). Assessment in higher education: drivers, barriers and directions for change in the UK. Assessment \& Evaluation in Higher Education, 41(1), 81-96. https://doi.org/10.1080/02602938.2014.982072

Murray, A. (2019). The role of practical assessment in the delivery of successful enterprise education. Education+ Training, 61(4), 413-431. https://doi.org/10.1108/ET-10-2018-0216

Naidoo, J. R., \& Mthembu, S. (2015). An exploration of the experiences and practices of nurse academics regarding postgraduate research supervision at a South African university. African Journal of Health Professions Education, 7(2), 216-219. https://doi.org/10.7196/AJHPE.443 
Orsmond, P., \& Merry, S. (2017). Tutors' assessment practices and students' situated learning in higher education: chalk and cheese. Assessment \& Evaluation in Higher Education, 42(2), 289-303. https://doi.org/10.1080/02602938.2015.1103366

Pearce, G., \& Lee, G. (2009). Viva voce (oral examination) as an assessment method: Insights from marketing students. Journal of Marketing Education, 31(2), 120-130. https://doi.org/10.1177/0273475309334050

Pickford, R., \& Brown, S. (2006). Assessing skills and practice. London: Routledge.

Quesada, V., Gómez Ruiz, M. Á., Gallego Noche, M. B., \& Cubero-Ibáñez, J.(2019). Should I use co-assessment in higher education? Pros and cons from teachers and students' perspectives. Assessment \& Evaluation in Higher Education, 44(7), 987-1002. https://doi.org/10.1080/02602938.2018.1531970

Sadler, D. R. (2016). Three in-course assessment reforms to improve higher education learning outcomes. Assessment \& Evaluation in Higher Education, 41(7), 1081-1099. https://doi.org/10.1080/02602938.2015.1064858

Santos Guerra, M. Á. (1993). La evaluación: un proceso de diálogo, comprensión y mejora. Revista Investigación en la Escuela, 20, 23-35.

Seifert, T., \& Feliks, O. (2019). Online self-assessment and peer-assessment as a tool to enhance student-teachers' assessment skills. Assessment \& Evaluation in Higher Education, 44(2), 169-185. https://doi.org/10.1080/02602938.2018.1487023

Shay, S. (2008). Beyond social constructivist perspectives on assessment: the centring of knowledge. Teaching in Higher education, 13(5), 595-605. https://doi.org/10.1080/13562510802334970

Shepard, L. A. (2000). The role of assessment in a learning culture. Educational Researcher, 29(7), 4-14. https://doi.org/10.3102/0013189X029007004

Thomas, D. P. (2009). Revisiting pedagogy of the oppressed: Paulo Freire and contemporary African studies. Review of african political economy, 36(120), 253-269. https://doi.org/10.1080/03056240903083268

Tlali, N., Mukurunge, T., \& Bhila, T. (2019). Examining the implications of massification of education on quality assurance and assessment in higher institutions in Lesotho. Int J Trend Scic Res Develop, 3(3), 1561-1568. https://doi.org/10.31142/ijtsrd23493

Vygotsky, L. (1978). Interaction between learning and development. Readings on the development of children, 23(3), 34-41.

Vygotsky, L. S. (1978). Mind in society: The development of higher psychological processes. Cambridge, MA: Harvard University Press.

Waghid, Y. (2011). The Decline of the University in South Africa: reconstituting the place of reason. In Barnett, R. (ed.). 2011. The Future University: ideas and possibilities. Buckingham: Open University Press.

Willems, W. (2013). Large Classes, Participation and the Potential of Educational Blogging: Personal Reflections of ExPress and ImPress Project. In Hornsby, D.J.; Osman, R., \& De Matos-Ala (Eds.). 2013. Large Class Pedagogy: Interdisciplinary Perspectives for Quality Tertiary Education. Johannesburg: Sun Media Metro. https://doi.org/10.18820/9780992180690/08

Winchester-Seeto, W., Mackayway, J., Coulson, D., \& Harvey, M. (2010). 'But how do we assess it?' an analysis of assessment strategies for learning though participation (LTP). Asia-Pacific Journal of Cooperative Education, 11(3), 67-91.

Wilson, M., \& Scalise K. (2006). Assessment to Improve Learning in Higher Education: the BEAR Assessment System. Higher Education, 52, 635-663. https://doi.org/10.1007/s10734-004-7263-y

Yorke, M. (2003). Formative Assessment in Higher Education: moves towards theory and the enhancement of pedagogic practice. Higher Education, 45, 477-501. https://doi.org/10.1023/A:1023967026413

Zlatkin-Troitschanskaia, O., Pant, H. A., \& Coates, H. (2016). Assessing student learning outcomes in higher education: challenges and international perspectives. https://doi.org/10.1080/02602938.2016.1169501

\section{Copyrights}

Copyright for this article is retained by the author(s), with first publication rights granted to the journal.

This is an open-access article distributed under the terms and conditions of the Creative Commons Attribution license (http://creativecommons.org/licenses/by/4.0/). 